\title{
Resistance to the Antibiotics Viomycin and Capreomycin in the Streptomyces Species Which Produce Them
}

\author{
By RICHARD H. SKINNER* AND ERIC CUNDLIFFE \\ Department of Biochemistry, University of Leicester, Adrian Building, \\ University Road, Leicester LE1 7 RH
}

(Received 24 January 1980; revised 24 April 1980)

\begin{abstract}
Viomycin and capreomycin, antibiotics produced by Streptomyces vinaceus and $S$. capreolus respectively, are potent inhibitors of bacterial protein synthesis. Although these organisms are highly tolerant of their own products in vivo, their ribosomes are fully sensitive to the action of the drugs in vitro. However, they possess novel, antibiotic-inactivating enzymes (viomycin phosphotransferase, capreomycin phosphotransferase, capreomycin acetyltransferase) which, in addition to possible biosynthetic roles, may contribute to the resistances observed in vivo.
\end{abstract}

\section{INTRODUCTION}

Viomycin and capreomycin are tuberculostatic peptide antibiotics (Fig. 1) produced by Streptomyces vinaceus and $S$. capreolus, respectively (Caltrider, 1967; Herr et al., 1960). Viomycin inhibits both the initiation and elongation phases of bacterial protein synthesis (Liou \& Tanaka, 1976) and in the latter context appears to be a specific inhibitor of translocation (Modolell \& Vazquez, 1977). Despite the fact that recent structural studies have revealed considerable differences between viomycin and the capreomycins (Nomoto et al., 1977), a conceptual association has long been established between these drugs and they are commonly assumed to act similarly.

Two sets of observations prompted us to examine the organisms which produce viomycin and capreomycin. Firstly, in various mutants of Mycobacterium smegmatis, resistance to both drugs could be determined by some undefined property of the RNA of either ribosomal subunit (Yamada et al., 1978). Secondly, in this laboratory (Cundliffe, 1978; Cundliffe \& Thompson, 1979) another antibiotic-resistance mechanism involving the state of ribosomal RNA (rRNA) had been elucidated. In this case $S$. azureus, which produces thiostrepton, defends itself by methylation of a specific ribose residue in $23 S$ rRNA. Accordingly, we wished to determine whether (and, if so, how) $S$. vinaceus and $S$. capreolus defend themselves against viomycin and capreomycin.

Here we report that these organisms are indeed resistant to their own toxic products, but in a manner radically different from that observed in $S$. azureus. They do not possess drugresistant ribosomes; rather, they elaborate novel, antibiotic-modifying enzymes which can inactivate viomycin and capreomycin in vitro and thus have the potential to participate in self-defence in vivo.

\section{METHODS}

Bacterial strains and media. Streptomyces coelicolor A(3)2 was provided by Professor D. A. Hopwood of the John Innes Institute, Norwich. Streptomyces vinaceus (NCIB 8852) and S. capreolus (NCIB 9801) were obtained from the National Collection of Industrial Bacteria, Aberdeen. Stock cultures of all organisms were maintained on $2 \%(\mathrm{w} / \mathrm{v})$ agar plates containing, per litre: $10 \mathrm{~g}$ glucose, $2 \mathrm{~g}$ yeast extract (Difco), $2 \mathrm{~g}$ 


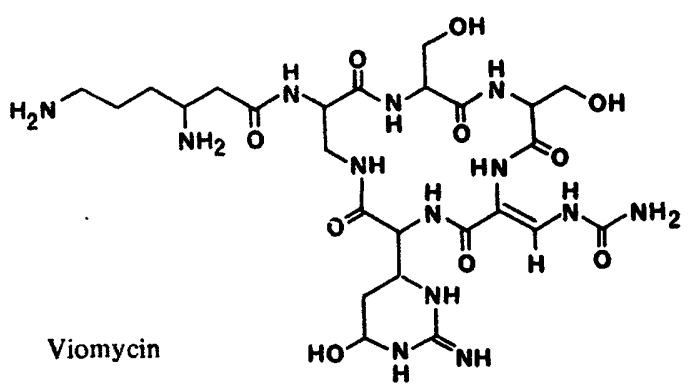

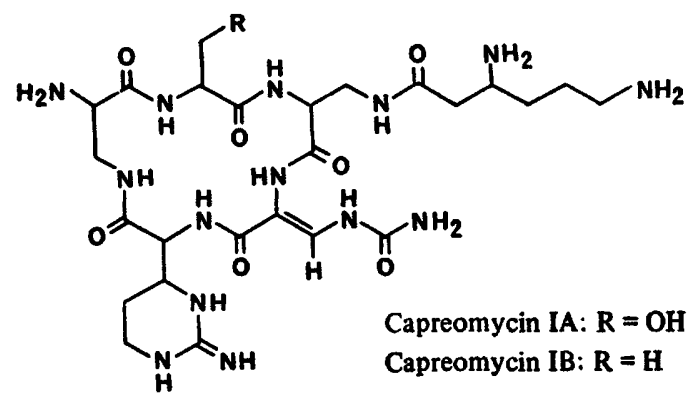

Fig. 1. The structures of viomycin and the capreomycins (Nomoto et al., 1977). Capreomycins IIA and IIB are minor components which differ from IA and IB in that they lack the $\beta$-lysine residue. The relative proportions of IA and IB vary, but together they usually account for at least $90 \%$ of the total capreomycin produced.

Casamino acids (Difco), $1 \mathrm{~g}$ Lab-Lemco beef extract (Oxoid). The $\mathrm{pH}$ value of the medium was adjusted to 7 with $\mathrm{KOH}$. In liquid culture, $S$. vinaceus and $S$. capreolus were grown in the above medium without agar, and $S$. coelicolor in a medium containing, per litre: $25 \mathrm{~g}$ nutrient broth no. 2 (Oxoid), $10 \mathrm{~g}$ glucose, $6 \mathrm{~g}$ $\mathrm{K}_{2} \mathrm{HPO}_{4}, 3 \mathrm{~g} \mathrm{KH}_{2} \mathrm{PO}_{4}, 5 \mathrm{~g}$ Casamino acids (Difco).

Growth of cells and preparation of extracts. Batch cultures were grown at $30^{\circ} \mathrm{C}(16 \mathrm{~h}$ for $S$. vinaceus and $S$. coelicolor, $4 \mathrm{~d}$ for $S$. capreolus) and cells were collected and washed either by centrifugation at $10000 \mathrm{~g}$ ( $S$. vinaceus and $S$. capreolus) or by filtration through Whatman no. 1 paper on a Buchner funnel (S. coelicolor). Cells were washed twice by resuspension in RS buffer $\left(10 \mathrm{~mm}-\mathrm{Tris} / \mathrm{HCl} \mathrm{pH} 7.6\right.$ at $20^{\circ} \mathrm{C}, 10 \mathrm{mM}$ $\mathrm{MgCl}_{\text {. }}, 50 \mathrm{~mm}-\mathrm{NH}_{4} \mathrm{Cl}, 3 \mathrm{~mm}$-2-mercaptoethanol) containing $0.5 \mathrm{~mm}$-EDTA, followed by re-collection as above.

Cell.free extracts (designated S30) were prepared by grinding with alumina followed by treatment with deoxyribonuclease and centrifugation at $30000 \mathrm{~g}$ as described elsewhere (Cundliffe et al., 1979).

Preparation of ribosomes and cell-free synthesis of protein. Ribosomes were prepared by layering the S30 over $0.33 \mathrm{vol}$. RS buffer containing $40 \%(\mathrm{w} / \mathrm{v})$ sucrose, followed by centrifugation at $100000 \mathrm{~g}$ for $14 \mathrm{~h}$ and resuspension in RS buffer. Postribosomal supernatant (designated $\mathbf{S 1 0 0}$ ) was dialysed at $0^{\circ} \mathrm{C}$ against a minimum of 500 vol. RS buffer and both ribosomes and S100 were rapidly frozen and samples stored at $-70^{\circ} \mathrm{C}$. Portions of $S$. capreolus $S 100$ to be used as a potential source of antibiotic-modifying enzymes were treated with $5 \%(\mathrm{w} / \mathrm{v})$ activated charcoal (Sigma) at $0^{\circ} \mathrm{C}$ for $5 \mathrm{~min}$ followed by centrifugation at $12000 \mathrm{~g}$ for $2 \mathrm{~min}$. This treatment was necessary in order to reduce the high 'background' in assays of acetyltransferase activity and probably involved removal of endogenous capreomycin.

Ribosomes and S100 were used to synthesize polyphenylalanine in response to polyuridylic acid [poly(U)] as described previously (Cundliffe et al., 1979) except that ribosomes were present at a final concentration of $0.4 \mu \mathrm{M}$ and incubation was at $30^{\circ} \mathrm{C}$. In all experiments, an incorporation of $10000 \mathrm{c.p} . \mathrm{m}$. represented approximately 2.5 residues of $\left[{ }^{14} \mathrm{C}\right]$ phenylalanine polymerized per ribosome.

Antibiotic-susceptibility tests. Suspensions of spores in $3 \mathrm{ml}$ of growth medium containing $0.5 \%(\mathrm{w} / \mathrm{v})$ agar were poured over $9 \mathrm{~cm}$ diam. nutrient plates (as above) and allowed to set. Paper dises (Whatman AA, $6 \mathrm{~mm}$ diam.) containing various antibiotics were placed on the plates which were incubated for $3 \mathrm{~d}$ at $30^{\circ} \mathrm{C}$.

Inactivation of viomycin and capreomycin IA by phosphorylation. Assay mixtures contained, in a final volume of $25 \mu \mathrm{l}$ RS buffer, $7.5 \mu \mathrm{l}$ S. coelicolor S100 or $2 \mu \mathrm{l}$ S. vinaceus S100 or $10 \mu \mathrm{l}$ S. capreolus S100 (previously treated with activated charcoal as above), 4 or $30 \mu \mathrm{M}$-antibiotic, and $2.5 \mathrm{mM}$-MgATP or $\beta, \gamma$-methylene adenosine triphosphate (AMPPCP). The time of incubation at $30^{\circ} \mathrm{C}$ was $10 \mathrm{~min}$, except for assays containing $S$. vinaceus $\$ 100$ and capreomycin IA, or $S$. capreolus $\$ 100$ and viomycin, which were incubated for $60 \mathrm{~min}$. The reaction was stopped by heating at $100^{\circ} \mathrm{C}$ for $5 \mathrm{~min}$, followed by centrifugation at $12000 \mathrm{~g}$ for $1 \mathrm{~min}$. Samples were removed and the residual drug activity was estimated following dilution (threefold) with the components required for in vitro protein synthesis. These included ribosomes and $\mathbf{S 1 0 0}$ from $S$. coelicolor.

Reactivation of phosphoviomycin by alkaline phosphatase. Viomycin was inactivated by incubation at $30{ }^{\circ} \mathrm{C}$. for $3 \mathrm{~h}$ in $100 \mu \mathrm{l}$ RS buffer containing $50 \mu \mathrm{l}$ S. vinaceus S100, $5 \mathrm{mM}$-MgATP and $13 \mu \mathrm{M}$-viomycin sulphate. A parallel incubation lacking drug was also carried out. The reaction was stopped by heating at $100^{\circ} \mathrm{C}$ for $5 \mathrm{~min}$, followed by centrifugation at $12000 \mathrm{~g}$ for $1 \mathrm{~min}$. Two samples were removed from each incubation mixture and diluted 15-fold with $\mathrm{RS}$ buffer lacking $\mathrm{NH}_{4} \mathrm{Cl}$. To one of each pair of samples, $E$. coli alkaline phosphatase [Sigma, 100 units $\mathrm{ml}^{-1}$ in $2.5 \mathrm{M}-\left(\mathrm{NH}_{4}\right)_{2} \mathrm{SO}_{4}$ ] was added to a final concentration of 1 unit $\mathrm{ml}^{-1}$. An equal amount of $\left(\mathrm{NH}_{4}\right)_{2} \mathrm{SO}_{4}$ was added to the remaining samples. After $20 \mathrm{~h}$ at $30^{\circ} \mathrm{C}$, the 

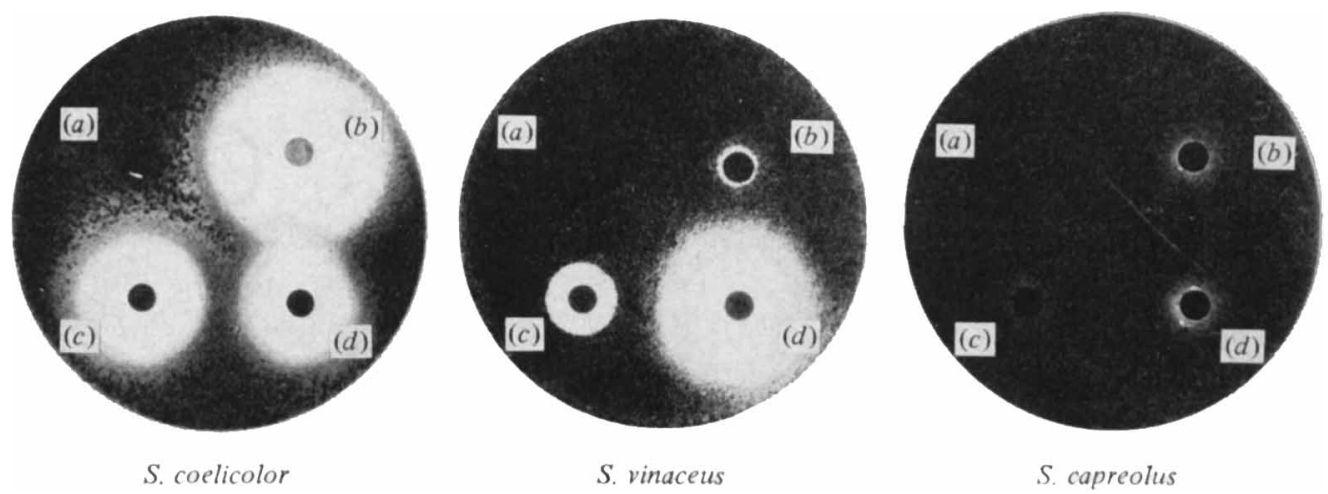

Fig. 2. Sensitivity of $S$. coelicolor, $S$. vinaceus and $S$. capreolus to viomycin and capreomycins in vivo. Discs contained: (a) blank; (b) $100 \mu \mathrm{g}$ viomycin; (c) $100 \mu \mathrm{g}$ capreomycin IA; (d) $100 \mu \mathrm{g}$ capreomycin IB.

antibiotic activity in each sample was estimated following dilution (threefold) with components required for in vitro protein synthesis, as above. Incubation was continued for a further $30 \mathrm{~min}$ at $30^{\circ} \mathrm{C}$ and the hot TCAinsoluble radioactivity in $10 \mu \mathrm{l}$ samples was determined.

Antibiotic-modification assays. Incubation mixtures contained, in a total volume of $25 \mu \mathrm{l} R S$ buffer, $10 \mu \mathrm{l}$ $S$. vinaceus or $S$. capreolus $S 100$ (the latter previously treated with activated charcoal as above), $30 \mu \mathrm{M}$ antibiotic and either $0.2 \mathrm{mM-}\left[\gamma-{ }^{32} \mathrm{P}\right] \mathrm{ATP}\left(10 \mathrm{mCi} \mathrm{mmol}^{-1}, 370 \mathrm{MBq} \mathrm{mmol}{ }^{-1}\right)$ or $0.2 \mathrm{~mm}-\left[1-{ }^{14} \mathrm{C}\right]$ acetyl-coenzyme A $\left(55 \mathrm{mCi} \mathrm{mmol}^{-1}, 2.03 \mathrm{GBq} \mathrm{mmol}^{-1}\right)$. After $30 \mathrm{~min}$ at $30^{\circ} \mathrm{C}$, samples $(20 \mu \mathrm{l})$ were delivered on to strips $(3 \times 1 \mathrm{~cm})$ of Whatman P81 phosphocellulose paper. These were washed four times with deionized water to remove unreacted radioactive cofactor and then twice with acetone. Radioactivity retained on the papers (representing modified antibiotic) was estimated by liquid-scintillation spectrometry. Background values obtained from control incubations lacking antibiotic were subtracted.

Purification of $\left[{ }^{14}\right.$ C] acety/capreomycins IA and IB. Capreomycins IA and IB were acetylated separately as described above, except that the final volume of the reaction mixture was $1 \mathrm{ml}$, the specific radioactivity of the [1-14 C]acetyl-coenzyme A was $7 \mathrm{mCi} \mathrm{mmol}^{-1}\left(260 \mathrm{MBq} \mathrm{mmol}^{-1}\right)$, and the time of incubation was $21 \mathrm{~h}$. The reaction mixtures were then applied to columns containing $1 \mathrm{ml} \mathrm{Amberlite} \mathrm{CG-50} \mathrm{Type} \mathrm{I}\left(\mathrm{NH}_{4}{ }^{+}\right.$form) which were washed with $4 \mathrm{ml}$ water to remove unreacted cofactor. Radioactive material eluted from each column with $2 \mathrm{ml} 2 \mathrm{M}$-acetic acid was collected, lyophilized, taken up in a small volume of water and applied to separate tracks on Whatman 3MM paper. The chromatogram was then developed by descending chromatography with $n$-butanol/acetic acid/water/pyridine (15:3:12:10, by vol.) for $16 \mathrm{~h}$. After drying, the tracks of the chromatogram were cut into $1 \mathrm{~cm}$ strips and the radioactivity in each was determined by liquid-scintillation spectrometry. The $\boldsymbol{R}_{\boldsymbol{f}}$ values of capreomycins IA and IB were $0 \cdot 10$ and $0 \cdot 12$, respectively, and those of the acetylated drugs were $0 \cdot 16$ and $0 \cdot 39$. Appropriate strips from each track were washed twice with toluene and then with acetone before being eluted at $37^{\circ} \mathrm{C}$ with $2 \%$ acetic acid. The eluates, purified $\left[{ }^{14} \mathrm{C}\right]$ acetylcapreomycins IA and IB respectively, were lyophilized and dissolved in small volumes of water.

Materials. Antibiotics were obtained from Sigma. Capreomycins IA and IB were purified by the method of Herr \& Redstone (1966) as modified by Nomoto et al. (1977). AMPPCP was a gift of Dr Ron Cooper, University of Leicester.

\section{RESULTS}

\section{Antibiotic-resistance in vivo}

In conventional disc-plate assays (Fig. 2), S. vinaceus was found to be highly resistant (but not entirely so) to viomycin, partially resistant to capreomycin IA and sensitive to capreomycin IB. In contrast, $S$. capreolus was almost completely resistant to all these drugs. Also included in Fig. 2 are results obtained with $S$. coelicolor (our standard reference actinomycete) which is sensitive to viomycin and the capreomycins. 


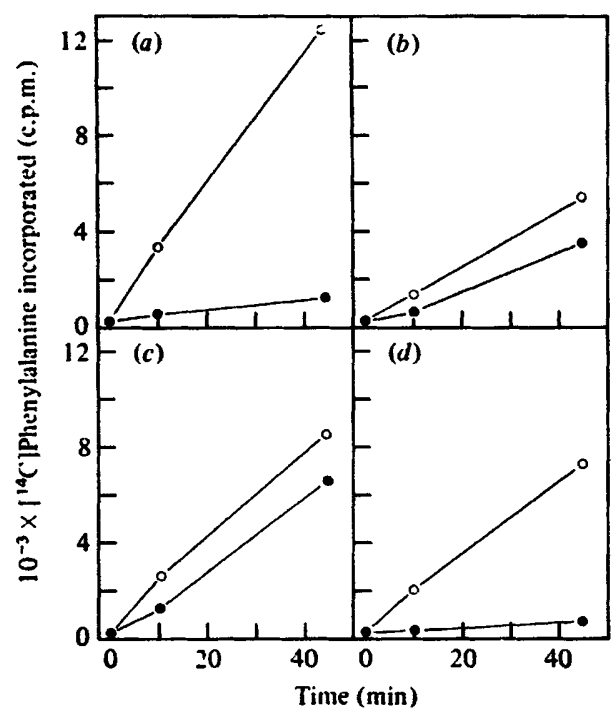

Fig. 3. Streptomyces vinaceus $\mathbf{S 1 0 0}$ determines resistance to viomycin. Polyphenylalanine synthesis was assayed as described in Methods: $O$, control;, , plus $1 \mu \mathrm{g}$ viomycin $\mathrm{ml}^{-1}$. (a) $S$. coelicolor

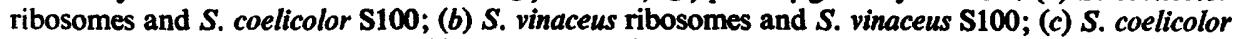
ribosomes and $S$. vinaceus $\mathbf{S 1 0 0 ;}(d) S$. vinaceus ribosomes and $S$. coelicolor $\mathbf{S 1 0 0}$.

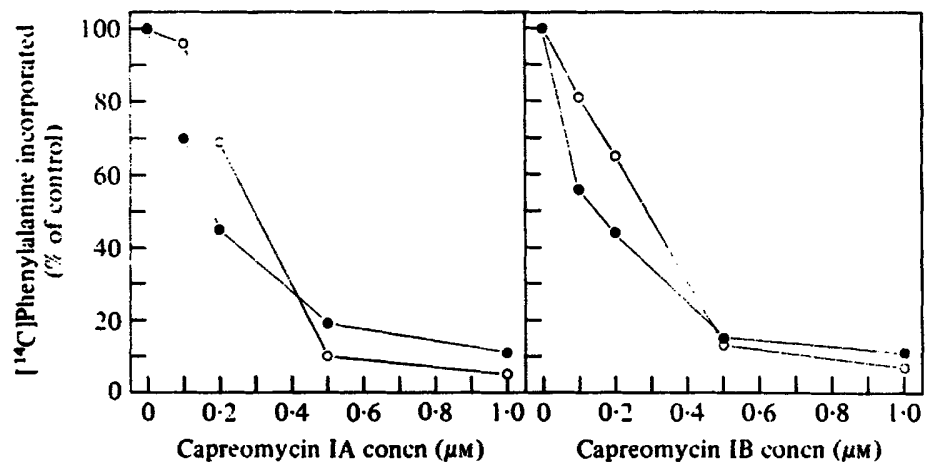

Fig. 4. Sensitivity of ribosomes of $S$. coelicolor and $S$. capreolus to capreomycins IA and IB. Cell-free protein synthesis was measured as described in Methods, using $\mathbf{S 1 0 0}$ from $S$. coelicolor and ribosomes from either $S$. coelicolor $(O)$ or $S$. capreolus $(0)$. The ribosomes had been washed in buffer containing $1 \mathrm{M}-\mathrm{NH}_{4} \mathrm{Cl}$ as previously described (Cundliffe et al., 1979). After $30 \mathrm{~min}$, control incorporation was 18000 c.p.m. and 2600 c.p.m., respectively.

\section{Antibiotic-resistance in vitro}

Cell-free extracts (S30), active in the poly(U)-directed synthesis of polyphenylalanine, were prepared from $S$. coelicolor and $S$. vinaceus. The rate of synthesis in extracts of $S$. coelicolor was decreased $50 \%$ by $50 \mathrm{ng}$ viomycin $\mathrm{ml}^{-1}$ whereas extracts of $S$. vinaceus were 200 to 300 times less sensitive to the drug. The crude extracts were then fractionated into ribosomes and postribosomal supernatant (S100) and reciprocal combinations of these were tested for their sensitivity to viomycin as above (Fig. 3). The results showed that resistance to viomycin was determined exclusively by the $S 100$ fraction from $S$. vinaceus and that the ribosomes of this organism were intrinsically sensitive to the antibiotic. In the light of these results, ribosomes were prepared from $S$. capreolus and tested (using S100 from $S$. coelicolor) for sensitivity of polyphenylalanine synthesis to capreomycins IA and IB (Fig. 4). Again, 


\section{Table 1. Inactivation of viomycin and capreomycin IA}

Viomycin or capreomycin IA at the concentrations specified were incubated with S100 from the organisms listed, with or without cofactor, and their subsequent inhibitory activity against cell-free polyphenylalanine synthesis was determined as described in Methods (final concentrations of antibiotics were one-third of the initial concentrations). In drug-free controls, synthesis proceeded linearly for at least 30 min at which time an average of 22000 c.p.m. of [ $\left.{ }^{14} \mathrm{C}\right]$ phenylalanine [5.5 pmol (pmol ribosomes) ${ }^{-1}$ ] had been incorporated per sample.

\begin{tabular}{|c|c|c|c|}
\hline Source of $\mathrm{S100}$ & Cofactor & $\begin{array}{c}\text { Antibiotic } \\
\text { (initial concn, } \mu \mathrm{M} \text { ) }\end{array}$ & $\begin{array}{r}\text { Inhibition of po } \\
\text { synther }\end{array}$ \\
\hline $\begin{array}{l}\text { S. coelicolor } \\
\text { S. coelicolor }\end{array}$ & ATP & $\begin{array}{l}\text { Viomycin (4) } \\
\text { Viomycin (4) }\end{array}$ & \\
\hline $\begin{array}{l}\text { S. vinaceus } \\
\text { S. vinaceus } \\
\text { S. vinaceus } \\
\text { S. vinaceus } \\
\text { S. vinaceus }\end{array}$ & $\begin{array}{l}\overline{-} \\
\text { ATP } \\
\text { AMPPCP } \\
\overline{-} \\
\text { ATP }\end{array}$ & $\begin{array}{l}\text { Viomycin (4) } \\
\text { Viomycin (4) } \\
\text { Viomycin (4) } \\
\text { Capreomycin IA (4) } \\
\text { Capreomycin IA (4) }\end{array}$ & \\
\hline $\begin{array}{l}\text { S. capreolus } \\
\text { S. capreolus } \\
\text { S. capreolus } \\
\text { S. capreolus }\end{array}$ & $\begin{array}{l}\overline{\text { ATP }} \\
\overline{\text { ATP }}\end{array}$ & $\begin{array}{l}\text { Capreomycin IA (30) } \\
\text { Capreomycin IA (30) } \\
\text { Viomycin (30) } \\
\text { Viomycin (30) }\end{array}$ & \\
\hline
\end{tabular}

\section{Table 2. Restoration of antibiotic activity of inactivated viomycin by alkaline phosphatase}

Viomycin (13 $\mu \mathrm{M})$ was inactivated by incubation with $S$. vinaceus S100 and ATP as described in Methods. Inactivated viomycin was then incubated with and without alkaline phosphatase, before its inhibitory effect against cell-free protein synthesis was determined (as in Table 1). Drug-free controls were included to compensate for the inhibitory effect of alkaline phosphatase on polyphenylalanine synthesis. In other controls, ATP was omitted from the initial incubation in order to show the effect of non-inactivated viomycin. The final concentration of viomycin (modified or unmodified) was $0 \cdot 3 \mu \mathrm{M}$.

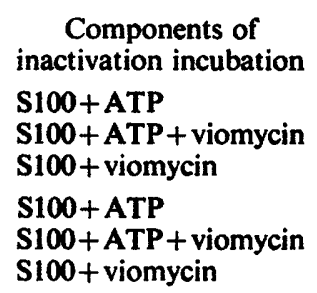

$\begin{array}{crr}\text { Phosphatase } & \overbrace{(\%)}^{c} \begin{array}{c}\text { Polyphenylalanine } \\ \text { synthesis }\end{array} & \text { (c.p.m.) } \\ - & 100 & 22800 \\ - & 108 & 24580 \\ - & 11 & 2450 \\ + & 100 & 16210 \\ + & 40 & 6540 \\ + & 8 & 1340\end{array}$

ribosomes of the producing organism were indistinguishable from those of $S$. coelicolor in their response to these antibiotics.

Since much evidence suggests that viomycin (and, by analogy, capreomycin) acts directly on ribosomes (e.g. Misumi \& Tanaka, 1978), it seemed unlikely that resistance to these drugs would be determined by any of the supernatant factors involved in protein synthesis. Rather, it seemed more probable that the producing organisms might contain enzymes capable of inactivating viomycin and capreomycin.

\section{Inactivation of viomycin and capreomycin IA}

The biological activity of viomycin or capreomycin IA (i.e. inhibition of cell-free protein synthesis) could be abolished by incubation with ATP together with S100 from either $S$. vinaceus or. S. capreolus (Table 1). Moreover, in the inactivation of viomycin, ATP could not be replaced by its non-hydrolysable analogue AMPPCP, nor could $S$. vinaceus $S 100$ be replaced by that from $S$. coelicolor. These results suggested that viomycin and capreomycin IA were being inactivated by phosphorylation, a conclusion substantiated by the further 
Table 3. Substrate specificity of viomycin- and capreomycin-modifying enzymes

Antibiotics $(600 \mathrm{pmol})$ were incubated with $S$. vinaceus or $S$. capreolus $S 100$ and either $\left[\gamma_{-}{ }^{32}\right.$ P]ATP or [1- 'C]acetyl-coenzyme $A$ and the extent of modification was determined as described in Methods.

\begin{tabular}{|c|c|c|c|}
\hline \multirow[b]{2}{*}{ Substrate } & \multicolumn{2}{|c|}{$\begin{array}{l}\text { [32P]Phosphate transferred } \\
\text { (pmol) }\end{array}$} & \multirow{2}{*}{$\begin{array}{c}{\left[{ }^{14} \mathrm{C}\right] \text { Acetate transferred }} \\
\text { (pmol) } \\
\text { S. capreolus } \\
\text { S100 }\end{array}$} \\
\hline & $\begin{array}{l}\text { S. vinaceus } \\
\mathbf{S 1 0 0}\end{array}$ & $\begin{array}{l}\text { S. capreolus } \\
\text { S100 }\end{array}$ & \\
\hline $\begin{array}{l}\text { Viomycin } \\
\text { Capreomycin IA } \\
\text { Capreomycin IB } \\
\text { Capreomycin IIA } \\
\text { Capreomycin IIB }\end{array}$ & $\begin{array}{r}76 \\
293 \\
1 \\
287 \\
0\end{array}$ & $\begin{array}{r}445 \\
604 \\
2 \\
488 \\
8\end{array}$ & $\begin{array}{c}7 \\
29 \\
49 \\
27 \\
61\end{array}$ \\
\hline
\end{tabular}

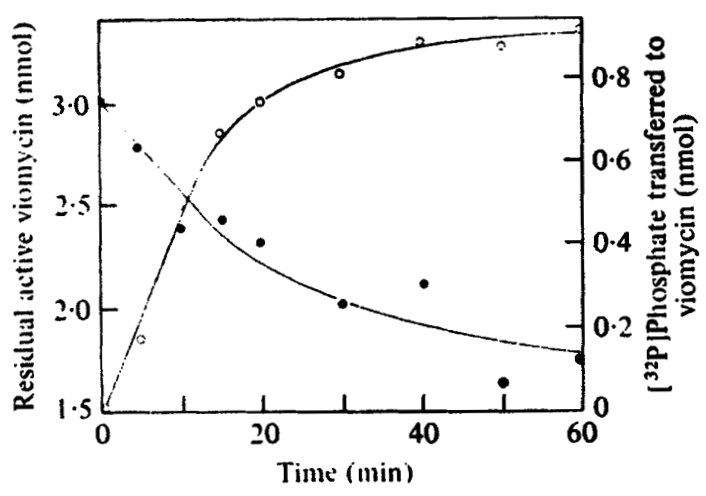

Fig. 5

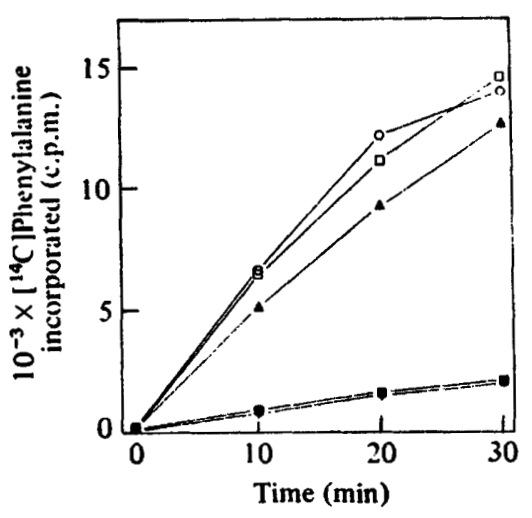

Fig. 6

Fig. 5. Inactivation and phosphorylation of viomycin by $\mathbf{S 1 0 0}$ from $S$. vinaceus. The following components (in $300 \mu \mathrm{l} R S$ buffer) were incubated together at $30^{\circ} \mathrm{C}: 30 \mu \mathrm{l} S$. vinaceus $\mathrm{Si00}, 16 \mu \mathrm{M}$ viomycin sulphate, $0.5 \mathrm{~mm}-\left[\gamma\right.$ - $\left.{ }^{22} \mathrm{P}\right] \mathrm{ATP}$. At intervals, $20 \mu 1$ samples were removed and phosphoviomycin was estimated by the phosphocellulose binding technique as described in Methods. Also, $5 \mu$ samples were diluted 15 -fold with $10 \mathrm{~mm}$-imidazole $/ \mathrm{HCl} \mathrm{pH} 6.8$ at $20^{\circ} \mathrm{C}$, heated at $100^{\circ} \mathrm{C}$ for $5 \mathrm{~min}$ and assayed for inhibition of polyphenylalanine synthesis using components from $S$. coelicolor. The residual amounts of active drug in the samples were estimated by comparison with the effects of known amounts of viomycin. $O$, Residual active viomycin; $O,\left[{ }^{32} \mathrm{P}\right]$ phosphate transferred to viomycin.

Fig. 6. Effect of acetylcapreomycins on cell-free polyphenylalanine synthesis by ribosomes and $\mathrm{S} 100$

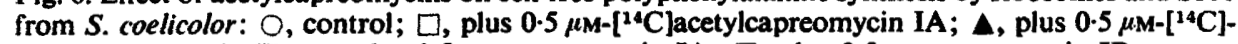

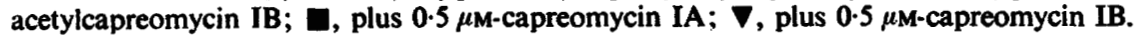

observation that inactivated viomycin was reactivated by incubation with alkaline phosphatase (Table 2). Subsequently, phosphotransferase activity was assayed directly using the phosphocellulose binding assay (Ozanne et al., 1969). Postively charged antibiotics, but not negatively charged radiolabelled ATP, are adsorbed to phosphocellulose paper. Using $\left[\gamma^{-32}\right.$ P]ATP and $S$. vinaceus $S 100$, it was found that viomycin was radioactively phosphorylated, and, furthermore, there was a reciprocal correlation between the extent of phosphorylation and the residual biological activity (Fig. 5). It appeared that approximately one molecule of phosphate was transferred per molecule of viomycin inactivated.

\section{Substrate specificity of antibiotic-modifying enzymes}

In addition to viomycin, capreomycins IA and IIA were substrates for the phosphotransferases of $S$. vinaceus and $S$. capreolus (Table 3). In this experiment, complete conversion of the antibiotics to phosphorylated product was not achieved because of the need to use 
less ATP (employed here in radiolabelled form) and more antibiotic than in the druginactivation experiments described above. Significantly, neither enzyme modified aminoglycosides such as streptomycin, neomycin, kanamycin or gentamicin (results not given) although these latter drugs are subject to inactivation by phosphorylation in other systems (for a review, see Davies \& Smith, 1978). We therefore conclude that the viomycin/capreomycin phosphotransferases of $S$. vinaceus and $S$. capreolus are novel, antibiotic-inactivating enzymes.

The results of Table 3 also show that all the capreomycins can be acetylated by extracts of $S$. capreolus. Moreover, when the acetylated forms of capreomycins IA and IB were purified by paper chromatography (see Methods), they were found to be inactive against protein synthesis in vitro (Fig. 6). Thus, 'capreomycin acetyltransferase' activity could contribute to the observed resistance of $S$. capreolus to both capreomycins IA and IB. In contrast, however, the 'capreomycin phosphotransferase' could only protect against capreomycin IA (and the minor component IIA). Although the IA component can be modified either by phosphorylation or by acetylation, these processes may be mutually exclusive since phosphocapreomycin IA could not be acetylated (results not given).

\section{Sites of phosphorylation of viomycin and capreomycin IA}

Phosphorylated viomycin is restored to antibiotic activity by incubation with alkaline phosphatase (Table 2). Also (results not given), the phosphate group is removed from [ $\left.{ }^{32} \mathrm{P}\right]$ phosphoviomycin and, at a lower rate, from [ $\left.{ }^{32} \mathrm{P}\right]$ phosphocapreomycin IA, by the same enzyme. Since phosphoamides are not substrates for bacterial alkaline phosphatase (Reid \& Wilson, 1971), these results eliminate the possibility that $N$-phosphorylation occurred. This conclusion is supported by the observation that radiolabelled phosphate was not released from phosphoviomycin by treatment with $1 \mathrm{M}-\mathrm{HCl}$ at $100^{\circ} \mathrm{C}$ for $60 \mathrm{~min}$, under which conditions $N$-phosphorylated compounds would be readily hydrolysed. Evidently, inactivation of these antibiotics involves $O$-phosphorylation. Radiolabelled phosphoviomycin and phosphocapreomycin IA were then subjected to partial hydrolysis in $2 \mathrm{M}-\mathrm{HCl}$ at 110 C for $4 \mathrm{~h}$ followed by high voltage paper electrophoresis at pH 1.9 (Jones \& Rodnight, 1971) or paper chromatography in solvent containing butanol/acetic acid/water (50:11:25, by vol.). In all hydrolysates, a substantial proportion of the total radioactivity co-migrated with $O$-phospho-L-serine which had been added prior to hydrolysis, while most of the remainder was identified as free phosphate (results not given). We therefore concluded that inactivation of viomycin and capreomycin IA resulted from phosphorylation of serine residues. In the case of capreomycin IA there is no ambiguity, but we cannot specify which of the two serines in viomycin is modified.

\section{Sites of acetylation of capreomycins}

The sites of acetylation of the capreomycins have not been unequivocally established. There are four potential sites: the $\alpha$-amino group of $\alpha, \beta$-diaminopropionic acid, the $\beta$ and $\epsilon$-amino groups of $\beta$-lysine, and the guanidinium group. In an attempt to distinguish between these possibilities, we compared the electrophoretic mobilities of acetylcapreomycins IA and IB with those of the unmodified antibiotics at various $\mathrm{pH}$ values. The rationale behind these experiments was that acetylation would result in a charge change of -1 at $\mathrm{pH}$ values below the $\mathrm{p} K_{\mathrm{a}}$ of the modified group and would reduce the electrophoretic mobility relative to unmodified drug. As shown in Table 4, the $\mathrm{p} K_{\mathrm{a}}$ value of the group acetylated in acetylcapreomycin IA was greater than 11 compared with about 8 for the group modified in acetylcapreomycin IB. Apparently, therefore, different groups were acetylated in the different capreomycins. We conclude that the guanidinium group is the probable site of acetylation in capreomycin IA; however, comparison of the published $\mathrm{p} K_{\mathrm{a}}$ values for capreomycin (Herr, 1963) with those of viomycin, $\beta$-lysine and $\alpha, \beta$-diamino- 
Table 4. Electrophoretic mobilities of $\left[{ }^{14} \mathrm{C}\right]$ acetylcapreomycins at various $\mathrm{pH}$ values

[ $\left.{ }^{11} \mathrm{C}\right]$ Acetylcapreomycins IA and IB, prepared as described in Methods, were subjected to high voltage paper electrophoresis in the buffers indicated $\left(50 \mathrm{mM}, \mathrm{pH}\right.$ measured at $\left.20^{\circ} \mathrm{C}\right)$ and their mobilities relative to the corresponding unmodified capreomycins were measured. Electrophoresis was at $33 \mathrm{~V} \mathrm{~cm}^{-1}$ for 2 to $4 \mathrm{~h}$. Markers were detected by u.v. absorbance or by the ninhydrin reaction. Distribution of radioactivity was measured by cutting the paper into $1 \mathrm{~cm}$ strips followed by liquid-scintillation spectrometry.

\begin{tabular}{|c|c|c|}
\hline \multirow[b]{2}{*}{ Buffer } & \multicolumn{2}{|c|}{ Relative mobility } \\
\hline & [ $\left.{ }^{14} \mathrm{C}\right]$ Acetylcapreomycin IA & {$\left[{ }^{14} \mathrm{C}\right]$ Acetylcapreomycin IB } \\
\hline $\begin{array}{l}\text { Tris/maieate pH } 5 \cdot 2 \\
\text { Tris/maleate pH } 7 \cdot 2 \\
\text { Glycine/NaOH pH } 9 \cdot 2 \\
\text { Triethanolamine/HCl pH } 11\end{array}$ & $\begin{array}{l}0.6 \\
0.6 \\
0.6 \\
0.4\end{array}$ & $\begin{array}{l}0.8 \\
0.7 \\
1.0 \\
1.0\end{array}$ \\
\hline
\end{tabular}

propionic acid (Dyer et al., 1965) suggests that the $\beta$-amino group of $\beta$-lysine(p $K_{\mathrm{a}} 7 \cdot 9$ )could be the site of acetylation in capreomycin IB.

Finally (results not given), we confirmed that $\left[1{ }^{14} \mathrm{C}\right]$ acetyl-coenzyme $\mathrm{A}$ acted as a source of acetyl and not carboxymethyl groups in these experiments. Total acid hydrolysis (6 M$\mathrm{HCl}, 100^{\circ} \mathrm{C}, 24 \mathrm{~h}$ ) of the presumptive $\left[{ }^{14} \mathrm{C}\right]$ acetylcapreomycins released radioactivity in a form (presumably acetic acid) which did not bind to phosphocellulose paper at pH 2.5 . $\left[{ }^{14} \mathrm{C}\right]$ Carboxymethylcapreomycins would have yielded radioactive degradation products that bound to phosphocellulose.

\section{DISCUSSION}

Antibiotic-producing organisms are frequently resistant to their products in vivo (Okami et al., 1969) but there have been relatively few detailed studies of the biochemical bases of such resistance. This is especially so in the case of those organisms which produce inhibitors of ribosome function, although Streptomyces erythreus and $S$. azureus possess ribosomes which fail to bind erythromycin and thiostrepton, respectively, and are thereby resistant to their own products (Teraoka \& Tanaka, 1974; Cundliffe, 1978). Otherwise, it is less clear how self-defence is achieved since, in all other cases so far examined, the ribosomes of the producing organisms were shown to be fully sensitive to the antibiotics in question. This latter group includes the producers of streptomycin (Cella \& Vining, 1974; Piwowarski \& Shaw, 1979), chloramphenicol (Malik \& Vining, 1972), and, as reported here, viomycin and capreomycin.

Several streptomycetes which produce aminoglycoside antibiotics contain aminoglycosideinactivating enzymes similar to those which exist as drug-resistance determinants in clinical isolates (Benveniste \& Davies, 1973). The question of whether any such enzyme plays a biosynthetic or protective role (or both) cannot, however, be resolved in the absence of other information. Relevant factors include the sensitivity of the ribosomes to the drug in question, the permeability properties of the cell membrane, and the possibility of intracellular compartmentalization. The present work shows that streptomycetes producing viomycin and capreomycin possess ribosomes which are entirely sensitive to these antibiotics. From this we infer that viomycin and capreomycin do not exist in these organisms in significant concentrations in the same cellular compartments as the ribosomes. Possibly the drugs are synthesized there as inactive precursors, or alternatively they may be produced in separate compartments. In the event that viomycin and capreomycins IA and IIA are produced intracellularly in phosphorylated form, one might predict the existence of phosphatases capable of restoring antibiotic activity extracellularly. In this context, it is noteworthy that the addition of inorganic phosphate to the culture medium of a viomycin-producing streptomycete severely inhibited antibiotic production with a concomitant repression of 
alkaline phosphatase activity (Pass \& Raczynska-Bojanowska, 1968). One wonders whether, under these conditions, viomycin accumulated as its phosphorylated derivative.

Under appropriate culture conditions, $S$. vinaceus and $S$. capreolus produce high external concentrations of viomycin and capreomycin, respectively, and, given that the ribosomes of these organisms are drug-sensitive, it seems logical to suppose that their cell membranes may be relatively impermeable to the drugs. As to the role of the antibiotic-modifying enzymes, they may be involved in the biosynthesis and/or export of the drugs and, since they require ATP or acetyl-coenzyme A as cofactors, we assume that they are either intracellular enzymes or are associated with the cytoplasmic membrane. These enzymes may additionally serve to protect the organisms from any antibiotic which re-enters the cells. If so, resistance is the result of a balance between uptake and inactivation such that the intracellular concentration of antibiotic remains subinhibitory. In this context, we note that $S$. vinaceus is considerably more resistant to capreomycin IA than to capreomycin IB (Fig. 2) and that its phosphotransferase can inactivate the former, but not the latter. On the other hand, $S$. vinaceus is substantially more sensitive to capreomycin IA than to viomycin (Fig. 2), even though the former antibiotic is a better substrate for the phosphotransferase (Table 3). This observation would be accounted for if the cell membranes of $S$. vinaceus were more permeable to capreomycin IA than to viomycin.

Regarding 'capreomycin acetyltransferase', it is not clear whether this activity is attributable to a single enzyme. Indeed, our results suggest that the sites of acetylation of capreomycins IA and IB may be different, which raises the possibility that there may be different acetyltransferases specific for different components of the capreomycin complex. However, our tentative identification of the sites of acetylation of these molecules requires confirmation by bulk synthesis and physico-chemical analysis. The minor components, capreomycins IIA and IIB, are also acetylated and we assume that they are thereby inactivated, although we have no information regarding the sites of modification.

Antibiotic-modifying enzymes occur widely in drug-resistant bacteria isolated in clinical situations (Davies \& Smith, 1978) and an attractive hypothesis suggests that plasmids encoding these enzymes may have acquired the relevant genes directly or indirectly from antibiotic-producing organisms (Walker \& Walker, 1970; Benveniste \& Davies, 1973). Viomycin and capreomycin have been used as tuberculostatic agents for some years and there are many reports of the clinical isolation of strains of Mycobacterium tuberculosis resistant to these antibiotics (Tsukamura, 1969; Algeorge \& Petre, 1970; McClatchy et al., 1977). It would be interesting to know whether any of these resistant strains contain antibiotic-modifying enzymes.

Note added in proof. In a 'shotgun' cloning experiment, resistance to viomycin was cloned from $S$. vinaceus into $S$. lividans on the vector SLP 1.2. Recombinant clones of $S$. lividans resistant to high levels of viomycin were cross-resistant to capreomycin IA but not to capreomycin IB, and extracts of these strains contained viomycin phosphotransferase activity. This enzyme was not, however, detected in the viomycin-sensitive parental strain of S. lividans (C. J. Thompson, J. M. Ward and D. A. Hopwood, unpublished results).

Our thanks are due to the M.R.C. for a project grant (to E.C.), to the S.R.C. for a Research Studentship (R.H.S.) and to Yvonne Ducommun for gifts of radiolabelled ATP.

\section{REFERENCES}

Algeorge, G. \& Petre, A. (1970). Some experimental aspects of cross-resistance between capreomycin and viomycin. Antibiotica et chemotherapia 16, 32-35.

Benveniste, R. \& Davies, J. (1973). Aminoglycoside antibiotic-inactivating enzymes in actinomycetes similar to those present in clinical isolates of antibiotic-resistant bacteria. Proceedings of the National Academy of Sciences of the United States of America 70, 2276-2280. 
Caltrider, P. G. (1967). Viomycin. In Antibiotics, vol. I, pp. 677-680. Edited by D. Gottlieb \& P. D. Shaw. Berlin: Springer-Verlag.

Cella, R. \& Vining, L. C. (1974). Action of streptomycin on growth of Streptomyces griseus. Canadian Journal of Microbiology 20, 1591-1597.

Cundliffe, E. (1978). Mechanism of resistance to thiostrepton in the producing organism, Streptomyces azureus. Nature, London 272, 792-795.

Cundliffe, E. \& Thompson, J. (1979). Ribose methylation and resistance to thiostrepton. Nature, London 278, 859-861.

Cundliffe, E., Dixon, P., Stark, M., Stöffler, G., Ehrlich, R., Stöffler-Meilicke, M. \& CanNon, M. (1979). Ribosomes in thiostrepton-resistant mutants of Bacillus megaterium lacking a single 50 S subunit protein. Journal of Molecular Biology 132, 235-252.

Davies, J. \& Smith, D. I. (1978). Plasmid-determined resistance to antimicrobial agents. Annual Review of Microbiology 32, 469-518.

Dyer, J. R., Kellogg, C. K., Nassar, R. F. \& Streetman, W. E. (1965). The structure of viomycin. Tetrahedron Letters, 585-592.

HerR, E. B. (1963). Chemical and biological properties of capreomycin and other peptide antibiotics. In Antimicrobial Agents and Chemotherapy-1962, pp. 201-212. Edited by J. C. Sylvester, Michigan: American Society for Microbiology.

Herr, E. B. \& Redstone, M. O. (1966). Chemical and physical characterization of capreomycin. Annals of the New York Academy of Sciences 135, 940-946.

Herr, E. B., Haney, M. E., Pittenger, G. F. \& Higgens, C. E. (1960). Isolation and characterization of a new peptide antibiotic. Proceedings of the Indiana Academy of Sciences 69, 134.

Jones, D. A. \& RoDNIGHT, R. (1971). Protein-bound phosphoserine in acid hydrolyzates of brain tissue. Biochemical Journal 121, 597-600.

Liou, Y.-F. \& TANAKA, N. (1976). Dual actions of viomycin on the ribosomal functions. Biochemical and Biophysical Research Communications 71, 477-483.

McClatchy, J. K., Kanes, W., Davidson, P. T. \& Moulding, T. S. (1977). Cross-resistance in $M$. tuberculosis to kanamycin, capreomycin and viomycin. Tubercle 58, 29-34.

MaLIK, V. S. \& VINING, L. C. (1972). Chlorampheni- col resistance in a chloramphenicol-producing Streptomyces. Canadian Journal of Microbiology 18, 583-590.

Misumi, M. \& TANaKa, N. (1978). Binding of $\left[{ }^{14} \mathrm{C}\right]$ tuberactinomycin $\mathrm{O}$, an antibiotic closely related to viomycin, to the bacterial ribosome. Biochemical and Biophysical Research Communications 82, 971-976.

Modolell, J. \& VazQuez, D. (1977). The inhibition of ribosomal translocation by viomycin. European Journal of Biochemistry 81, 491-497.

Nomoto, S., Teshima, T., WakamiYa, T. \& Shiba, T. (1977). The revised structure of capreomycin. Journal of Antibiotics 30, 955-959.

Okami, L., Hashimoto, T. \& Suzuki, M. (1969). Sensitivity of actinomycetes to antibiotics as a guide to identification. Journal of Antibiotics 13, 223-227.

Ozanne, B., Benveniste, R., Tipper, D. \& Davies, J. (1969). Aminoglycoside antibiotics: inactivation by phosphorylation in Escherichia coli carrying $\mathrm{R}$ factors. Journal of Bacteriology 100, 1144-1146.

PASs, L. \& RACZYNSKA-BOJANOWSKA, K. (1968). On the inhibition mechanisms of viomycin synthesis by inorganic phosphate. Acta biochimica polonica 15, 355-367.

Piwowarski, J. M. \& Shaw, P. D. (1979). Streptomycin-resistance in a streptomycin-producing organism. Antimicrohial Agents and Chemotherapy 16, 176-182.

REID, T. W. \& WILSON, I. B. (1971). E. coli alkaline phosphatase. In The Enzymes, vol. IV, 3rd edn, pp. 373-415. Edited by P. D. Boyer, New York: Academic Press.

Teraoka, H. \& Tanara, K. (1974). Properties of ribosomes from Streptomyces erythreus and Streptomyces griseus. Journal of Bacteriology 120 , 316-321.

Tsukamura, M. (1969). Cross-resistance relationships between capreomycin, kanamycin and viomycin resistances in tubercle bacilli from patients. American Review of Respiratory Disease 99, 780-782.

Walker, M. S. \& Walker, J. B. (1970). Streptomycin biosynthesis and metabolism. Journal of Biological Chemistry 245, 6683-6689.

Yamada, T., Mizuguchi, Y., Nierhaus, K. H. \& WitTMANN, H. G. (1978). Resistance to viomycin conferred by RNA of either ribosomal subunit. Nature, London 275, 460-461. 